\title{
1. Your Teaching Philosophy
}

The justification for a university is that it preserves the connection between knowledge and the zest for life, by uniting the young and the old in the imaginative consideration of learning. (Whitehead, 1929: 139)

If you are looking for instruction on what to teach your students and how to do so, this book will disappoint you. If you are looking for help to discover just how important you are to your students' learning, read on. This book could just have easily been titled how to allow students to learn about entrepreneurship. Parker Palmer ${ }^{1}$ said there is 'no question that students who learn, not professors who perform, is what teaching is all about ... [however] teachers possess the power to create conditions that can help students learn a great deal - or keep them from learning much at all'. Throughout this chapter, it is my intention to invite you to locate yourself and visualise the necessary journey from sage-on-the-stage, to guide-on-the-side, to meddlerin-the-middle that will aid your students' learning. ${ }^{2}$ It is my hope that through understanding how my teaching philosophy has developed and influenced the learning outcomes of my students, you will gain entry to a place from which to reflect upon how you could teach entrepreneurship. Along the way, I hope you benefit from the introductions to the many educators who have influenced my approach to teaching entrepreneurship. First, some initial thoughts that have accompanied me throughout my initial nine years of teaching entrepreneurship. This chapter is therefore highly reflective.

I have always felt that entrepreneurial learning is not related to memorising external bodies of knowledge, but rather it is about selfrecognition of internal knowledge. It is not always about events that are planned or predictable, but frequently about unplanned and unpredictable events. It is less about the knowledge of the educator, and more about the support of the educator. It is about the creation of what doesn't exist, rather than the maintenance of that which does. It is about freedom, not restriction, and it is as much about failure as it is success. These initial thoughts have accompanied me (relatively unchanged) throughout my short career as a teacher. 


\section{THE DEVELOPMENT OF MY TEACHING PHILOSOPHY}

As a student I was disengaged, and an abject failure throughout my formal schooling. My grades improved once I embarked upon an apprenticeship as a diesel fitter due to the fact that it was vocational education relying upon my experiential learning. My father was a teacher and I observed his genuine desire to help his students to achieve their desired outcomes. By chance, in the shadows of a spectacular (and life altering) business failure, ${ }^{3}$ I found myself faced with an opportunity to teach, having only just graduated with a university degree, believing three things: first, teachers should aim to help their students; second, all students should be fully engaged in the learning process; and lastly, teaching and learning need to be based on honest reflection from all participants. The immediate challenge to the development of my teaching philosophy was recognition of how all the learning bits related to each other. Figure 1.1 below illustrates my simplified take on the situation I was immediately faced with as a teacher of entrepreneurship.

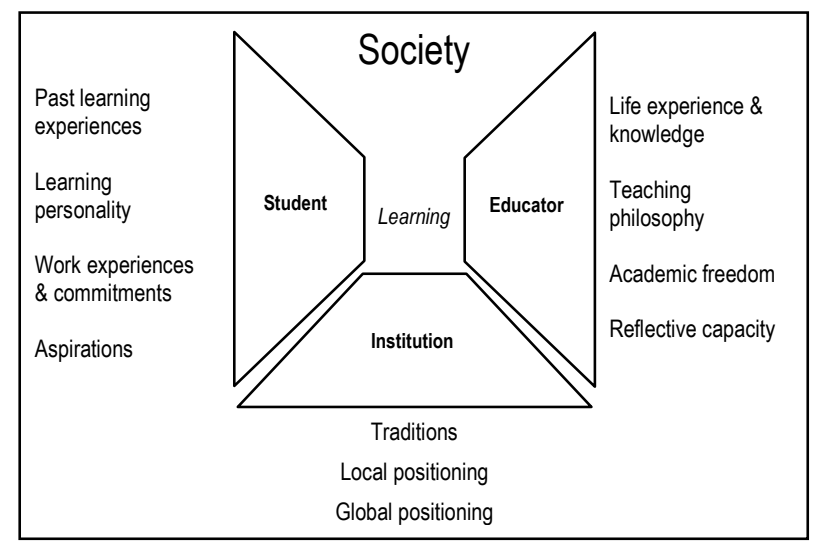

Figure 1.1 Simplified context of teaching in higher education

In the context of higher education, learning is situated between the interactions of individual students and the educators they encounter within a particular institutional environment. The learning environments encountered by students will vary markedly due to student participation, the nature of the subject area, educator contribution and institutional customs. Individual students will have different past life/learning experiences, differing learning personalities, differing work experiences and ongoing commitments and will hold different personal aspirations. The educators will have different life 
experiences and knowledge. They will undoubtedly have different (implicit or explicit) teaching philosophies. Depending upon the status they hold, they will also have varied levels of academic freedom and demonstrate differing commitments to personal reflection. Also, the traditions and local and global positioning of any institution will influence the nature of interactions occurring between students and educators. Finally, our colleagues and institutional cultures may hold vested interests as to how student-educator interaction should occur. Does this sound familiar? Given the dynamic nature of EE, the development of a desirable teaching philosophy can clearly be disrupted by several factors, many of which may not be controllable. The challenge is to understand where you are placed regarding your current teaching philosophy; generally a written statement of your approach to teaching that essentially remains forever a work in progress.

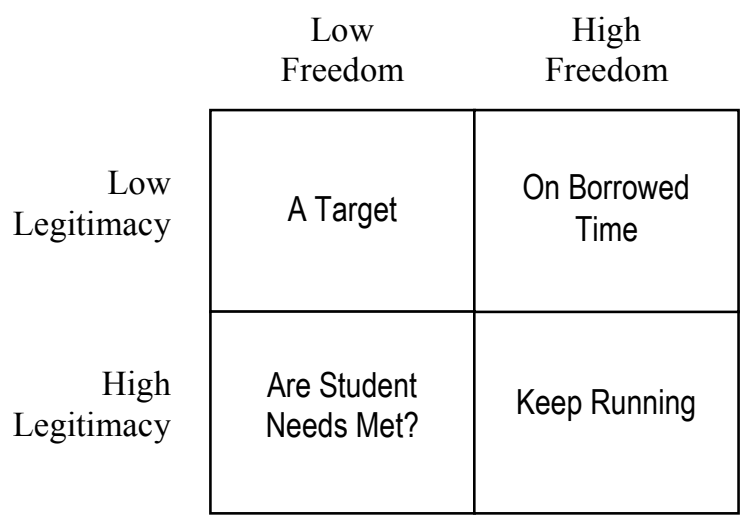

Figure 1.2 Simplified context of your teaching philosophy

In Figure 1.2 above, a simplified context for the operation of your teaching philosophy is offered for your consideration. Regardless of whether you have or have not had the opportunity to formally write down your teaching philosophy, I argue that teaching entrepreneurship requires of us much vigilance as to how we protect ourselves from external perceptions of our teaching practices. If your approach to teaching has low legitimacy from colleagues who provide you with little freedom to do your own thing, you are a target for those that wish to stamp out acts of (perceived) deviance; persons that might typically prefer to protect their system/s. You need to achieve high legitimacy for your teaching practices. Institutional, national and disciplinebased teaching awards are an obvious way of gaining such legitimacy. But without gaining more freedom, the needs of your students may still not be being addressed due to possible constraints by your peers. 
Low legitimacy and high freedom is a better situation to operate in, but are you on borrowed time if your practices become known by all? Again the issue of legitimacy looms large. Only when you are free to address the actual needs of your students in a manner that has gained institutional legitimacy will EE be truly rewarding to you as a professional educator. However, even when you have achieved high legitimacy and high freedom, the challenge is to continue to do so. As you add more learning activities to your repertoire and encounter change in the workplace, the essence of your teaching philosophy will remain under threat. I have met very few educators in this field that feel totally free to operate as they please. Indeed, in a recent survey of international educators teaching EE (herein referred to as the IE Survey), ${ }^{4}$ at least $50 \%$ of all respondents felt some constraint to the way they choose to teach entrepreneurship from their colleagues, school, faculty or institution. With reference to the development of EE at UTAS, let me reflect upon the development of my own teaching philosophy.

\section{A Personal Journey}

When EE was introduced at UTAS in 2002, my colleague and I decided that, based on the literature that we had engaged with, ${ }^{5}$ a learner-centred approach would be most appropriate. We both had much start-up experience, but neither of us had handed the class over to the students before. It was nerve racking to begin with, but we could see that there was more potential to engage students by handing over responsibility for the learning to them than retaining power and authority in the classroom. Not long after we had started my colleague moved to another institution to start another EE programme. I was left to run the programme at a time when I had also enrolled in a Graduate Certificate of Teaching and Learning. So, a relatively inexperienced teacher, given increased freedom whilst also being increasingly exposed to educational theory. In reality, this was the point in time that my assumed components of a teaching philosophy came into contact with my first real reflections of what my approach should and could be to EE. Looking back, an iterative process of deep reflection (illustrated in Figure 1.3 below) has been continually occurring ever since.

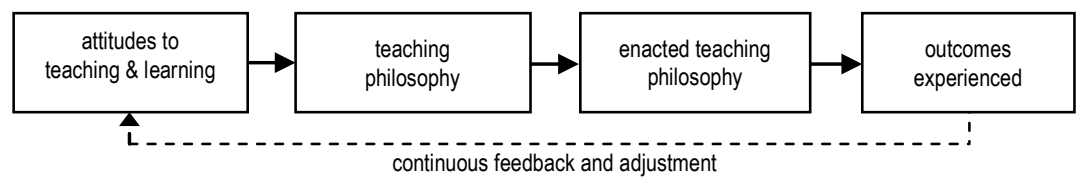

Figure 1.3 Iterative development of your teaching philosophy 
Initially, the work of John Biggs ${ }^{6}$ introduced me to many important ideas and provided me with profitable access to many seminal contributors to the educational literature. His process of constructive alignment enabled me to organise my feedback into three simple questions. What do my students need to learn? What learning activities would best enable my students to achieve the desired learning outcomes? And, what forms of assessment would allow me to know if the students have achieved the intended learning requirements? Given the complexity of teaching EE, I found this a simple, but challenging to implement process, a wonderful tool. It provided the backdrop to the development of my teaching philosophy.

My curiosity of the EE literature led me to the various works of Allan $\mathrm{Gibb}^{7}$ and his notions that we as educators should create learning environments within which students experience the way of life of an entrepreneur, allowing them to walk in the entrepreneur's shoes so to speak. The notion that we should grant our students more freedom and ownership of their learning, that we should allow them to create their learning opportunities and use their social capital to reduce the risks associated with such an approach, seems very appropriate. At the same point in time, I also became aware of the work of Stephen Brookfield, ${ }^{8}$ who proposed four critically reflective lenses through which one can view their teaching: autobiographies as teachers and learners, our students' eyes, our colleagues' experiences, and contributing to the theoretical literature. A hunger to blend discipline-based and pure educational theory was well and truly developing.

As my attitudes to teaching and learning changed, so did my teaching philosophy, and likewise the activities planned for my students. The next influential work I encountered was from Ralph Tyler. ${ }^{9}$ Tyler asserted that 'learning takes place through the active behaviour of the student: it is what he [or she] does he [or she] learns, not what the teacher does'. To me, this represented a licence to get out of the way, to accept the challenge of Gibb to transfer more responsibility to my students. But it also required of me to better understand the process of how my students might benefit from such an approach. Observing the students reflecting on their behaviours between workshops and watching them adapt to their ever-changing learning environment led me naturally to use evolutionary theory to explain the process.

Thorstein Veblen's ${ }^{10}$ work provided a means to consider how the students' habits of thought could be altered. Viewing the learning environment as the source of constant selective pressures, it was assumed that assessment processes would eventually favour those students most capable of adapting to the prevailing selection forces. I was less interested in whether it was the environment selecting for particular temperaments, or 
whether it was the adaptive ability of the students to changing circumstances that produced new habits of thought. After all, Veblen had expressed the view strongly that such processes had no identifiable starting or finishing point. He felt that 'the evolution of society is substantially a process of mental adaptation on the part of individuals under the stress of circumstances which will no longer tolerate habits of thought formed under and conforming to a different set of circumstances in the past'. The process was assumed to be an inexact process of adjusting inner relations to outer relations, made surer by the degrees of freedom surrounding the process, with student reflection a critical factor in the process. This ensured that the students had the opportunity to draw breath between workshops and contemplate what behaviours to retain, and what to add based on their assessment of the selection (i.e. assessment) forces in their learning environment.

\section{The Inspiration of Whitehead}

With my confidence growing as I fed off the feedback and enthusiasm of the students, I was introduced to the work of Alfred Whitehead ${ }^{11}$ listening to a presentation by Kevin Hindle on EE. Impressed by Kevin's conviction as to the value of Whitehead's ideas, I obtained a copy of Whitehead's work and read it from cover to cover, several times. The ideas are breathtaking, and worthy of consideration by every educator, regardless of their subject domain. The key idea being that our students should learn in their here and now, that we as educators should identify the key principles related to their study and disregard all else that hinders their excited engagement and progress. In essence, less is more. Combined with the subject-specific ideas of Allan Gibb, my teaching philosophy became focused upon ensuring that everything my students did evoked their immediate interest in the subject area, that it exercised their mental capabilities, and that they exhibited such mental capabilities for all to see. I felt free, released by the wisdom of ghosts long past, whose ideas seemed timeless and highly relevant to my students' learning.

By this stage, the learning activities being prepared for my students were being radically overhauled from one teaching period to the next. New ideas from other educators met at conferences were being adopted and modified to suit the needs of my students. It was at this point in time when the legitimacy of my efforts was most under threat. I was operating in the high freedom/low legitimacy space, and I was on borrowed time. Two specific things enabled me to achieve legitimacy and scramble into a space where if I could keep moving forward, my teaching philosophy could remain in it's ever alteringform. The first was recognition at the 2005 Australian Awards for University Teaching, being named the Early Career Educator of the year. This award 
and its associated prestige created a lot of breathing space and essentially denied those that questioned the validity of my teaching practices a voice. During this time, I was also reflecting upon my teaching through conference and journal publications. This process helped me to build credible arguments as to why my students should engage in such learning activities, why they should take increasing responsibility for their learning outcomes, and why EE is different from traditional business school subjects.

However, during 2006 I was forced to accept that despite the general student excitement/engagement and the start-up success of a few students, the focus of my teaching practice was misplaced. By and large, my graduated students were not starting up new businesses. They seemed to be doing well with their careers, but were they entrepreneurs? I think the honest answer was no, from the perspective of the traditional usage of the term entrepreneur.

The most important implication to arise from this revelation was that my focus needed to be more on the development of the student, rather than on the development of their start-up aspirations; Chapter 4 will deal with this issue in more detail. During this time, I began to engage with the student development literature, starting with the works of William Perry, Robert Brown and Clyde Parker. ${ }^{12}$ This led to the discovery of several works by Marcia Baxter-Magolda, ${ }^{13}$ a champion of educational leadership in higher education. Her work on the concept of self-authorship seemed very appropriate to the domain of EE, and will also be further discussed in Chapter 4. However, my teaching philosophy, most influenced up until that point in time by the works of Allan Gibb and Alfred Whitehead, was slipped into overdrive through the unearthing of the relatively unknown work of Roy Heath. $^{14}$

\section{An Overt Focus on Personal Development}

Whilst the opportunity for students to develop a business idea to market operation remains, a more general aim related to helping the students develop the attributes of a reasonable adventurer has emerged as the primary driver of their personal development. As discussed previously: ${ }^{15}$

Heath defines the reasonable adventurer as a graduate student capable of making his or her own opportunities for satisfaction. A disposition argued to be a necessary pre-condition for engaging in entrepreneurial behaviours. Heath alludes to six specific attributes through which a student's ability to create their opportunities for satisfaction were enhanced. The first attribute is intellectectuality, the ability to alternate between being a believer and a sceptic. An ability to remain curious whilst determining what matters through making connections between the object under consideration and the reality of their world. The second attribute is close friendships, or the ability to discover the individuality of others. The realization that they have shared feelings with others and that prior 
perceptions have been altered due to these friendships. The third attribute is independence in value judgements, or the ability to rely upon personal experience rather than known external authorities. This increased reliance upon one's judgement provides an avenue towards self-reflection that may be travelled with much vigour and enthusiasm. The fourth attribute is a tolerance of ambiguity, or the ability to view life as a series of interruptions and recoveries, ${ }^{16}$ to be able to suspend judgements until sufficient information is obtained to make the right decision. The fifth attribute is the breadth of interest demonstrated. Heath calls this an uncommon interest in the commonplace. So depth replaces breadth to enable the sustained pursuit of specific problems. The last attribute is a balanced sense of humour. A benign, but lively sense of humour that distinguishes the reasonable adventurer, making he or she good company, and capable of being sensitive towards others across conflicting circumstances.

So a fully functioning graduate capable of using his or her individuality in ways beyond their prior mental endowments. A student connected to the reality of their world, yet able to find deep satisfaction from the ingredients of their raw life. Through the adoption of the reasonable adventurer concept, a new, exciting and obtainable minimal benchmark for my graduating students was established. One that would dovetail nicely into the creation of enterprise-related skills developed in the UTAS programme. Importantly, I had six attributes around which learning activities could be crafted and assessed. To lock in the potential gains possible from this approach, students moved beyond personal reflections to participation in a process of group sense making ${ }^{17}$ through which they gained a heightened sense of their feeling and those of their fellow students.

The latest change to my teaching philosophy has been my recent development of a 4 Cs framework to further bring to life the ideas of all works previously noted in an authentic way. The 4Cs framework requires that within every entrepreneurship unit/module at UTAS, students must conceive new value, they must create it, they must capture it, and most importantly, they must critique their efforts to do so. I am trying to ensure they are constantly walking in the entrepreneur's shoes (Gibb), always in their here and now (Whitehead) whilst developing a sense of what they could be (Baxter-Magolda) through the development of key attributes related to their capacity to create opportunities for personal satisfaction (Heath) from an iterative reflective process (Tyler). My work as the meddler in the middle is continuously simplified through my ongoing reliance upon the process of constructive alignment to disassemble and reassemble the pieces of the jigsaw puzzle that is the entrepreneurship curriculum at UTAS.

Why this approach? I agree wholeheartedly with the sentiments of Professor Kazem Chaharbaghi ${ }^{18}$ that entrepreneurs tend to be found in society more than they are born into society or made in society. As educators we have an opportunity to enable our students to discover themselves. At the 
heart of this thinking is an acceptance on my behalf that more than half of what our students need to learn resides within, that it is our challenge to allow a process of self-awareness to occur simultaneously whilst they walk in the shoes of the entrepreneur. Thus, I conclude that my (current) teaching philosophy can be stated as: I wish for my students, the attainment of entrepreneurial knowledge that leads to entrepreneurial wisdom. I want my students to discover themselves in the lives they live. I want my students to be excited about learning and fearless of failing in the same breath. I want my students to be able to create opportunities for satisfaction within and after their university studies.

Let us now briefly consider the evolution of the UTAS programme as contrasted to changes in my teaching philosophy (see Figure 1.4 below). From its inception in what I would now term a naive appreciation of learnercentred learning, my teaching philosophy has been continuously altered through constant exposure to the ideas of entrepreneurship educators and educational scholars. Throughout this process, an increasing importance has been given to personal and group reflection. Where multiple learning activities have been used, greater choice has been provided to students to account for individual differences, and the learning experience has moved as Allan Gibb would say, from learning about enterprise, to learning for enterprise, on to learning through (or in) enterprise. The current influences on the development of my teaching philosophy (and therefore refinement of the learning activities and assessment procedures used) are my developing appreciation of the application of critical realism in the domain of educational research. ${ }^{19}$

\begin{tabular}{|c|c|c|c|c|}
\hline & Stage 1 & Stage 2 & Stage 3 & Stage 4 (current) \\
\hline $\begin{array}{r}\text { Influences } \\
\text { Upon } \\
\text { Teaching } \\
\text { Philosophy }\end{array}$ & $\begin{array}{l}\text { Naiive sense of } \\
\text { learner-centred } \\
\text { learning } \\
\text { USA EE literature }\end{array}$ & $\begin{array}{l}\text { Blending of Allan } \\
\text { Gibb's ideas with } \\
\text { Whitehead, Tyler } \\
\text { and Biggs }\end{array}$ & $\begin{array}{l}\text { Personal/character } \\
\text { development } \\
\text { Literature (Heath, } \\
\text { Perry, Baxter- } \\
\text { Magolda etc) }\end{array}$ & $\begin{array}{l}\text { The ontological } \\
\text { issues related to } \\
\text { assessing, teaching } \\
\text { \& understanding my } \\
\text { students' learning }\end{array}$ \\
\hline $\begin{array}{r}\text { Learning } \\
\text { Activities } \\
\text { Typically } \\
\text { Used }\end{array}$ & $\begin{array}{l}\text { Task drive workshop } \\
\text { presentations } \\
\text { Large written } \\
\text { assignment }\end{array}$ & $\begin{array}{l}\text { Multiple activities } \\
\text { aimed at student } \\
\text { engagement, cases, } \\
\text { games and group } \\
\text { presentations }\end{array}$ & $\begin{array}{l}\text { Multiple activities } \\
\text { aimed at student } \\
\text { engagement, cases, } \\
\text { games and group } \\
\text { presentations + } \\
\text { more choice }\end{array}$ & $\begin{array}{l}\text { Multiple activities + } \\
4 \mathrm{Cs} \text { (conceive, } \\
\text { create, capture and } \\
\text { critique) }\end{array}$ \\
\hline $\begin{array}{r}\text { Weighting and } \\
\text { Focus of } \\
\text { Assessment }\end{array}$ & $\begin{array}{l}\text { Exam - } 40 \% \\
\text { Presentations - 30\% } \\
\text { Reflection- } 0 \%\end{array}$ & $\begin{array}{l}\text { Exam-25\% } \\
\text { Presentations - } 15 \% \\
\text { Reflection-22.5\% }\end{array}$ & $\begin{array}{l}\text { Exam - 25\% } \\
\text { Presentations - 30\% } \\
\text { Reflection - } 45 \%\end{array}$ & $\begin{array}{l}\text { Exam - } 25 \% \\
\text { Presentations - 30\% } \\
\text { Reflection- } 45 \%\end{array}$ \\
\hline
\end{tabular}

Figure 1.4 Evolution of teaching philosophy and curriculum 
At the heart of this unfolding process is a litany of mistakes and illconceived learning activities. Herein lies the ultimate challenge for the entrepreneurship educator: do you have the humility and courage to fail in order to succeed in helping your students? It is not possible to adopt an off the shelf curriculum from afar that will suit the needs of your students better than your reasoned development of a process that accommodates their specific needs. To do so outsources your primary responsibility as an educator, that being the determination of what your students need to learn. Put simply, adopting a text before you adopt a curriculum is selling your students short. Sure, be guided by many of the excellent works that have emerged in recent times, but do not allow yourself to become a slave to someone else's (possibly undisclosed) teaching philosophy.

\section{The Context of Your Teaching Philosophy}

I adopt the above stated position not to argue for the rejection of textbookdriven approaches to EE, as texts have a place in our domain. Rather, I seek to draw attention to a raft of dialogic relationships that surround the process of your teaching; relationships that will undoubtedly impact upon the development of your teaching philosophy and its enactment. By dialogic relationships, reference is being made to the fact that we cannot explain our students' outcomes without reference to our contribution and vice versa. Dialogic relationships exist between educators-students, educators-institutions, students-institutions, learning environments -educators etc. When you consider the context within which you develop your teaching philosophy, you must account for the many seemingly invisible relationships which may remain beyond your control. Clearly, such relationships will differ between educators in different institutions. Thus, what works for one, may not work for another. Yet, in adopting many texts and their prescribed content and suggested learning activities, we do so potentially without giving sufficient consideration of the dialogic relationships that have supported the development of such texts.

I invite you to revisit those texts, to seek out the authors' declaration of their teaching philosophies. Does it not seem strange that a body of work is offered to assist in the teaching of entrepreneurship without explanation of how this offering will allow our students to learn? The focus far too often is upon what the students should learn rather than how the students could learn about entrepreneurship. If we don't understand the various ways our students learn then we risk disengaging many by offering a one size fits all approach. This is an issue that will be addressed in more detail. However, let us briefly consider how colleagues in EE address the issue of teaching philosophies. 


\section{THE NATURE OF EE TEACHING PHILOSOPHIES}

The IE Survey asked respondents to briefly state their teaching philosophy, their approach to EE and whose past (or current) work has most influenced their approach. Interestingly, not one respondent nominated a recognised educational theorist as contributing to their teaching philosophy. It would seem (see Figure 1.5 below) that it is very common within EE for teachers to be influenced by textbooks and the colleagues they interact with more so than any other external influence. If such a finding were to be representative of a broader pattern of behaviour globally within EE, it raises some important questions. Are our students fortunate that good teaching practices are being inherited through the texts and advice of leading scholars in the domain of EE? Or, is there an over-reliance upon the artefacts of other peoples' practice? While neither question will be answered here, the implications of each question should be reflected upon by the reader.

Parker Palmer ${ }^{20}$ argues that good teaching is less about methods and more about the degree to which we as educators know and trust ourselves. That is there is a need to be vulnerable to the students and the learning environments we operate within. He further argues that we should avoid using artefacts (such as textbooks) to shield ourselves from the dangers we might perceive to exist in the learning environments we share with our students. But we wish to assist our students to learn about a truly complex subject, a subject that is rarely about objective facts typically found in textbooks. More commonly, it is learnt through experience and the use of imagination and reflection as encouraged by us the educators.

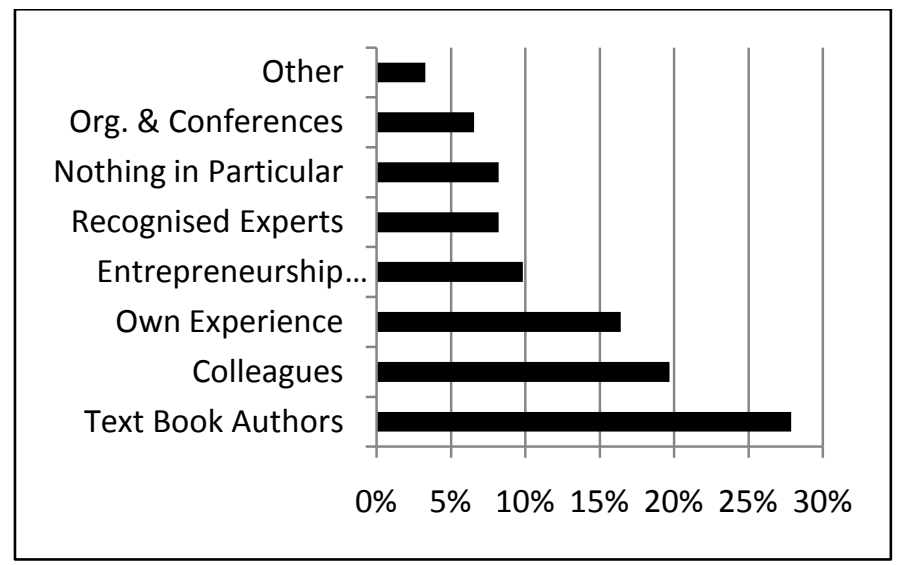

Figure 1.5 Sources of influence on teaching philosophy 


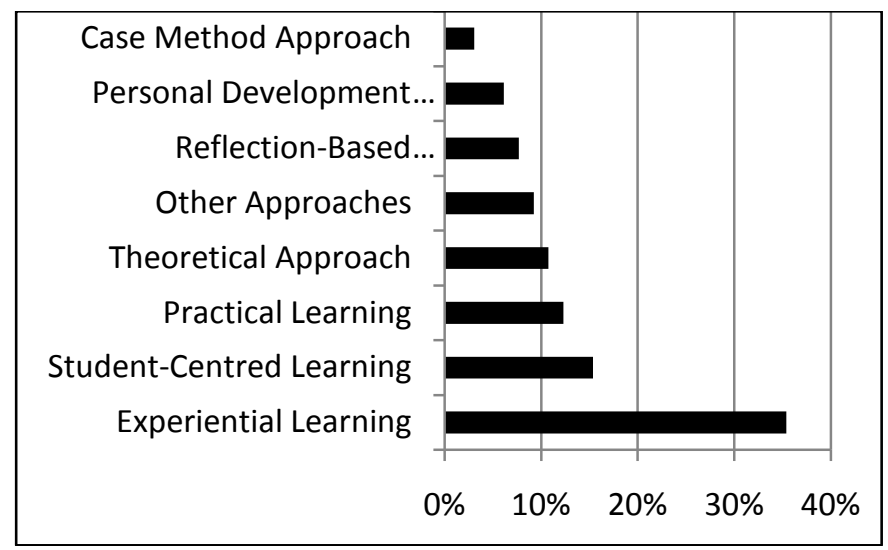

Figure 1.6 Types of approaches used to teach entrepreneurship

When asked to describe their approach to EE (see Figure 1.6), the IE Survey respondents identified several (non-exclusive) approaches to their teaching practice. Experiential, learner-centred and practical approaches are the most reported approaches to teaching EE. In reality, it is evident from the respondents' answers describing how they used their nominated approach, that various combinations of these approaches are frequently used to deliver EE. Let us now turn our attention to your teaching philosophy.

\section{DEVELOPING YOUR TEACHING PHILOSOPHY}

A statement of your teaching philosophy can be developed for various reasons. Increasingly such statements are developed to assist in gaining employment in higher education, gaining recognition of one's practice, or for gaining personal advancement within your institution. This section is focused upon developing a deep consideration of who you are as an educator, what relationships you wish to develop/maintain with your students, and ultimately how you will assist them to learn. Therefore, our focus is on an applied teaching philosophy for you and your students' advancement, rather than a documented teaching philosophy for your personal advancement.

In its simplest form a teaching philosophy should cover the essence of: how you believe your students learn; what you believe they should learn; what should be the impact of such learning; what activities they should engage with to learn; what type of learning environment is required to facilitate the delivery of such learning activities; how you will assess the nature of their learning; and how you will implement and monitor/adjust your 
teaching philosophy. There are many resources available online to assist you through this process of thinking about your teaching; but the most important resource is you.

To begin with, how do you believe your students learn? There are many cultural, institutional and individual (student) factors that will impact upon this issue as well as your own beliefs on the matter. Does your conception of learning relate to the memorisation of facts or does it extend to the development of wisdom? Is there a common process through which all students learn or do they differ in terms of how they learn? The answers to these questions inform you as to what you believe and/or accept within the conditions within which you teach. In essence you are working with your epistemological beliefs for they are the foundations of your teaching philosophy.

The next question is what do you believe your students need to learn? No one can answer this question for you. You know the context of their learning, of their situation within your institution. Are you involved in the delivery of EE within a team or do you operate by yourself? Do you have several units/modules with your students or just one unit/module? What is the overarching aim of your programme/course? Is it to produce entrepreneurs in the business start-up sense or is it to produce entrepreneurial types capable of dealing with the complexity of an ever-changing world, or both?

Next, what should be the impact of such learning? Are there types of students you believe your programme/course should be capable of producing? Are there some specific enterprising skills and/or critical thinking skills that must be developed to ensure the attainment of your desirable learning outcomes? In what ways might the students be expected to behave in order to succeed in your programme/course? How might this desirable form of behaviour differ from their other studies?

Next, what activities are required to facilitate your students' learning? How much legitimacy do your desirable learning activities have with your students, colleagues or faculty? Is there a change in behaviour required for the students to complete your learning activities? If so, how will you encourage trust from the student group to fully engage with the activities?

Next, what type of learning environment is required to facilitate the delivery of such learning activities? Do you require more interaction by the students? If you need to get out of their way, are they ready to take on more responsibility for their learning? Do they need to feel safe? How will you ensure they feel safe?

Next, how will you assess the nature of their learning? Will your learning activities create more assessable items? Will you be able to give useful and timely feedback? Will your approach to assessment fit in with the prevailing norms at your institution? Can you defend your approach if need be? 
Finally, how will you implement and monitor/adjust your teaching philosophy? Who or what will provide you with feedback as to how successful your teaching philosophy is? Are there goals you can establish against which you can measure your progress? Have you a plan to reflect upon your development as an educator?

The above should not be taken as an exhaustive list of what must be addressed to develop your teaching philosophy. Your teaching philosophy is yours and will differ appropriately depending upon the various dialogic relationships that you operate within. The key is that you accept there is no real starting point; that has already occurred. There will never really be an end point, just many sequential points along the way where you can consciously adjust your approach as you search for continuous feedback of your approach.

In summary, this opening chapter sought to introduce you the reader to my own personal feelings of how I approach my students' enterprise learning. The aim was not to offer you an approach for you to consider the merits of, but alternatively to encourage you to reflect upon what you believe. I have attempted to convince you that it is through your own self-discovery that you will determine how you will teach entrepreneurship. That an over-reliance upon the standardised ideas of others will reduce your ability to identify and understand the particular conditions of your teaching that are specific to you and unlikely to be shared by others located in different contexts. To this end, the development of a teaching philosophy is argued to provide you with an opportunity to renew your interest in truly understanding your students' experiences of learning. My final word of encouragement on this issue is to reassure you that the process is made all the easier through working closely with your students. When students know you are interested in their learning outcomes and willing to explain what you are trying to achieve with them, an interesting thing can happen. First, they gain a deeper understanding of their required role in the learning environment. They sense what is required from them to gain the most from the experience. Second, they develop a sense of trust and belonging to the processes that are unfolding around them. They appreciate what is being attempted for them. Lastly, and most importantly, they become very forgiving of planned activities that fall short of expectations. I maintain that good educators will always push the envelope too far on occasions. In doing so, access to honest feedback is critical so that corrections can be implemented. I simply ask my students frequently how they are feeling about our progress during the semester and at the end of the semester I ask them what we should keep, what we should add and what we should remove. Throughout this process, being a teacher is fun and personally rewarding, regardless (within reason) of the outcomes being achieved. 
Prior to discussing the central issues presented in this book, we will briefly detour to consider the history of EE, the current approaches and debates that are helping shape the space that we operate within. I hope you can continue throughout this book with an open mind, continually reflecting upon your feelings and the context you operate within.

\section{NOTES}

1. See Palmer (1997: 7).

2. See Erica McWilliam (2009).

3. Prior to becoming a lecturer at the University of Tasmania I was an active entrepreneur for many years building businesses in financial services, home services and the importation of farming machinery. Serious difficulties experienced with my home services (franchised) business led to a fall from grace. Staring at bankruptcy, I became a student of marketing and economics at the University of Tasmania to gain access to legal aid to seek legal remedy to my financial predicament. Eventually failing to avoid bankruptcy, I graduated and was offered a position as a pracacademic in a newly formed undergraduate program in entrepreneurship at UTAS.

4. The IE Survey is based upon the responses of 97 entrepreneurship educators from 35 countries and was conducted to assist the research process of this book (see Appendix 1 for details of the respondents).

5. See Jones and English (2004).

6. See Biggs (2003).

7. See Gibb (2002).

8. See Brookfield (1995).

9. See Tyler (1949: 63)

10. See Veblen (1925: 192).

11. The work of Whitehead (1929) has shaped my teaching philosophy more than other works I have encountered.

12. See Perry (1968), Brown (1972) and Parker (1978).

13. See Baxter-Magolda (1998; 2004).

14. See Heath (1964).

15. See Jones (2007: 230).

16. See Dewey (1922).

17. See Hart et al. (1998).

18. Professor Kazem Chaharbaghi, University of East London, Royal Dock Business School.

19. See Scott (2001).

20. See Palmer (1997). 